\title{
Relationship Between Flag Leaf Symptoms Caused by Xanthomonas translucens pv. translucens and Subsequent Seed Transmission in Wheat
}

\author{
K. M. Tubajika, Department of Plant Pathology and Crop Physiology, B. L. Tillman, Department of Agronomy, \\ J. S. Russin and C. A. Clark, Department of Plant Pathology and Crop Physiology, and S. A. Harrison, \\ Department of Agronomy, Louisiana State University Agricultural Center, Baton Rouge 70803
}

\begin{abstract}
Tubajika, K. M., Tillman, B. L., Russin, J. S., Clark, C. A., and Harrison, S. A. 1998. Relationship between flag leaf symptoms caused by Xanthomonas translucens pv. translucens and subsequent seed transmission in wheat. Plant Dis. 82:1341-1344.

The relationship between foliar disease symptoms on parent plants, seed contamination by the causal bacterium (Xanthomonas translucens pv. translucens), and subsequent development of bacterial leaf streak in wheat was studied in microplots and in the laboratory to determine the role of seed transmission in disease epidemiology. Microplot experiments were carried out during the 1994-95 and 1995-96 growing seasons using seed harvested in Baton Rouge, Louisiana, in 1994 and 1995, respectively. Treatments were seed lots from plants with differing levels of bacterial leaf streak severity on the flag leaves of the parent tillers. X. translucens pv. translucens was detected in 1 to $20 \%$ of seed from susceptible cultivars Florida 304 and Savannah collected from plants with leaf streak symptoms. Correlations between seed contamination and disease on plants that developed from this seed were detected only when seed came from parent tillers that expressed flag leaf disease severity $\geq 15$ to $20 \%$ in $1994-95$ and $\geq 30$ to $35 \%$ in 1995 96. However, symptoms of bacterial leaf streak on plants that developed from these seed were evident on only $\leq 3 \%$ of plants. Results suggest a possible threshold level for bacterial leaf streak on flag leaves that is necessary before $X$. translucens pv. translucens can be detected in seed. Seedling emergence in microplots correlated negatively with leaf streak severity on parent tiller flag leaves. Artificial infestation of seed with X. translucens pv. translucens also reduced seed germination, but this was more evident in Savannah than in Florida 304.
\end{abstract}

Additional keywords: dissemination, seed pathology, spread, Triticum aestivum

Bacterial leaf streak (BLS), caused by Xanthomonas translucens pv. translucens, was first reported in 1902 from wheat (Triticum aestivum L.) in Indiana (23). Since then, $X$. translucens pv. translucens has been detected in several wheat production areas in the United States and other countries (28). This pathogen causes two distinct symptoms on wheat. Leaf streak begins as water-soaked lesions that elongate rapidly following the parallel venation of the leaf. The lesions dry and become necrotic, resulting in leaves with a streaked or blotched appearance $(3,4,8)$. Yield loss is related to leaf streak (25). Black chaff refers to partial or complete darkening of the glumes and peduncles (23) and can be confused with false black chaff (7), which

Corresponding author: K. M. Tubajika

E-mail: Ktubaj@1suvm.sncc.lsu.edu

Present address of second author: RiceTec, Inc., P.O. Box 1305, Alvin, TX 77512.

Present address of third author: Department of Plant, Soil and General Agriculture, Southern Illinois University, Carbondale 62901.

Accepted for publication 27 August 1998.

Publication no. D-1998-1016-01R

(C) 1998 The American Phytopathological Society can be caused by UV or high relative humidity in the absence of the bacterium. In individual cultivars, symptom severity for leaf streak is independent of that for black chaff (24). Losses due to the disease usually have been minor, with occasional reports of severe loss in individual fields (8). However, a yield reduction of $40 \%$ has been reported from sprinkler irrigated fields in Idaho (8).

Seed, crop debris, alternative hosts, and soil have been reported as means by which $X$. translucens pv. translucens is disseminated $(2,15,22,23,28)$. However, in southern states such as Arkansas, this pathogen does not survive over summer in crop debris or soil cropped to wheat (19). Boosalis (2) observed local dissemination of the bacterium through rain, dew, and contact between plants. Limited spread of the pathogen in the field (18) and low rates of pathogen transmission from seed to plant $(10,20)$ have been reported. Seed transmission of the pathogen was reported by Jones et al. (13), who recommended the use of pathogen-free seed to limit BLS. The pathogen may both infest $(21,23)$ and infect seed (27).

Most published reports on seed transmission and detection of $X$. translucens pv. translucens have been carried out with naturally contaminated seed (6-8). Mehta
(16) used seeds of wheat, rye, and triticale with varying degrees of natural bacterial contamination by $X$. translucens pv. undulosa and $X$. translucens pv. hordei to develop techniques for managing these bacteria in cereal seeds. Forster and Schaad (8) also used naturally contaminated durum wheat seed in studies on eradication of $X$. translucens pv. translucens. Duveiller et al. (7) used wheat seed lots harvested from highly diseased plots to detect $X$. translucens pv. undulosa in Mexico. Despite the assumption that infected (or infested) seed are important for pathogen spread, little research has been conducted on the relationship between planting contaminated (infested) seed and severity of disease produced in the subsequent crop. This study addresses the role of contaminated seed in the epidemiology of $X$. translucens pv. translucens by examining the correlation between contaminated seed and subsequent disease development from that seed. A preliminary report has been published (26).

\section{MATERIALS AND METHODS}

Bacterial isolates and inoculum production. $X$. translucens pv. translucens strains Xtt 90-1, 41, and 42 were isolated from diseased wheat plants in East Baton Rouge (cv. Coker 9766), Acadia (cv. FFR 525W), and Concordia (cv. Florida 302) parishes, Louisiana, respectively, during springs of 1989 and 1990. These strains were maintained on silica gel at $-20^{\circ} \mathrm{C}$. Before inoculation, several silica gel crystals harboring each isolate were placed onto Wilbrink's medium (4). When colonies developed, bacterial cells were transferred into liquid 523 medium (21) and incubated at $24^{\circ} \mathrm{C}$ for 3 days on an orbital shaker at $200 \mathrm{rpm}$. Bacteria were suspended in $10 \mathrm{ml}$ of sterile phosphate-buffered saline $\left(6.8 \mathrm{~g}\right.$ of $\mathrm{KH}_{2} \mathrm{PO}_{4}, 1.16 \mathrm{~g}$ of $\mathrm{NaOH}$, and $8.5 \mathrm{~g}$ of $\mathrm{NaCl}$ per liter of distilled water, $\mathrm{pH}$ 7.0). Inoculum concentrations were adjusted to an optical density of 0.10 at $620 \mathrm{~nm}$, which yielded approximately $10^{8} \mathrm{CFU} \mathrm{m}{ }^{-1}$.

Seed sources. Susceptible winter wheat cultivars Florida 304 and Savannah were used in these studies. Savannah expresses black chaff symptoms and Florida 304 does not; both express leaf streak symptoms $(24,25)$. One plot of each cultivar was planted in Baton Rouge on 8 November 1993 and 24 November 1994. Plots were approximately $40 \mathrm{~m}$ square. Plots were 
treated with the fungicide propiconazole (1[2-(2,4-dichlorophenyl)-4-propyl-1,3-dioxolan-2-y1]-1H-1,2,4-triazole) on 3 March 1994 and 26 March 1995 at Feekes' growth stage 8 (14) to protect plants against foliar fungal diseases. Plants were inoculated with a mixture of the three virulent strains of $X$. translucens pv. translucens on 11 and 25 March 1994 and on 10 and 28 March 1995. Single tillers were tagged, and the percentage of the flag leaf area showing symptoms of leaf streak was estimated at Feekes' growth stage 11.2 (soft dough) using assessment keys and diagrams developed by James (12) and Duveiller (5). Individual spikes from marked tillers were harvested and threshed by hand. Seeds from each tiller were grouped into disease classes based on BLS severity on flag leaves from parent tillers. Seeds from each class were used in both microplot and laboratory studies. A portion of seeds from each class was bulked and treated at $72^{\circ} \mathrm{C}$ for 5 days to kill naturally occurring $X$. translucens pv. translucens (9); these were used as control treatments in microplots.

Recovery of $X$. translucens pv. translucens from seed. Three replicates (100 seeds each) were removed from each flag leaf severity class in both cultivars prior to planting in microplots. Seeds were placed individually in $1.5-\mathrm{ml}$ microcentrifuge tubes containing $0.5 \mathrm{ml}$ of sterile phosphate-buffered saline containing $0.02 \%$ Tween 20. These were shaken for $10 \mathrm{~min}$ and allowed to settle for $2 \mathrm{~min}$. Triplicate platings of serial 10-fold dilutions were made on Wilbrink's boric acid-cephalexin (WBC) agar (4). Plates were incubated at $28^{\circ} \mathrm{C}$ in darkness and examined after 4 to 5 days for $X$. translucens pv. translucens. The percentage of seeds colonized by the pathogen was determined, and numbers of CFU per seed were calculated. Yellow mucoid colonies characteristic of $X$. translucens pv. translucens and similar to the original culture were inoculated in greenhouse tests to confirm pathogen identity. Greenhouse-grown Savannah wheat plants were inoculated at the fiveleaf stage (14). Suspensions prepared from cultures on WBC were adjusted to $10^{8}$ $\mathrm{CFU} \mathrm{ml} \mathrm{m}^{-1}$ as described previously. Plants were inoculated using an artist's airbrush pressurized by $\mathrm{CO}_{2}\left(1.38 \times 10^{5} \mathrm{~Pa}\right)$ that delivered $0.5 \mathrm{ml} \mathrm{s}^{-1}$. Plants were sprayed until completely wet and were evaluated for BLS symptoms over a period of 14 days.

Contaminated seed and subsequent disease development. Microplot experiments were carried out during the 1994-95 and 1995-96 growing seasons using seed harvested in Baton Rouge in 1994 and 1995, respectively. Treatments were seed from plants with differing levels of bacterial leaf streak severity on flag leaves from parent tillers and were replicated six times. Experiments were conducted in microplots arranged in a randomized complete block design. Each microplot consisted of a large clay pot $(30 \mathrm{~cm}$ diameter) that contained $15 \mathrm{~kg}$ of silt loam soil (coarse-silty, mixed, nonacid, thermic Aeric Fluvaquent). Twelve seeds per pot were planted on 6 November 1994 and 11 November 1995. Pots were buried in soil up to the rims and spaced $1 \mathrm{~m}$ apart. The entire area was cov-

Table 1. Relationships between bacterial leaf streak severity on flag leaves, seed infested by Xanthomonas translucens pv. translucens, bacterial populations in seed, seedling emergence, and incidence of diseased plants in Baton Rouge, Louisiana ${ }^{\mathrm{a}}$

\begin{tabular}{cccccc}
\hline Cultivar & FLS $(\boldsymbol{\%})^{\mathbf{b}}$ & $\begin{array}{c}\text { Seed infested } \\
(\boldsymbol{\%})^{\mathbf{c}}\end{array}$ & $\begin{array}{c}\text { Bacterial population } \\
(\text { CFU/seed) }\end{array}$ & $\begin{array}{c}\text { Seedling } \\
\text { emergence }(\boldsymbol{\%})\end{array}$ & $\begin{array}{c}\text { Plants } \\
\text { diseased }(\boldsymbol{\%})^{\mathbf{d}}\end{array}$ \\
\hline Florida 304 & 0 & 0 & 0 & 100 & 0 \\
& 5 & 0 & 0 & 50 & 0 \\
& 10 & 0 & 0 & 50 & 0 \\
& 15 & 0 & 0 & 50 & 0 \\
& 20 & 2 & 2,000 & 58 & 1 \\
& 30 & 2 & 3,050 & 42 & 1 \\
& 60 & 20 & 4,113 & 58 & 2 \\
& 90 & 20 & 3,200 & 42 & 3 \\
& $r=$ & 0.91 & 0.81 & -0.39 & 0.72 \\
& $P=$ & 0.0001 & 0.0001 & 0.056 & 0.0001 \\
& 0 & 0 & 0 & 100 & 0 \\
& 5 & 0 & 0 & 83 & 0 \\
& 10 & 0 & 0 & 83 & 0 \\
& 15 & 3 & 378 & 75 & 0 \\
& 20 & 7 & 1,643 & 75 & 1 \\
& 30 & 10 & 2,060 & 75 & 1 \\
& 70 & 12 & 4,680 & 58 & 2 \\
& $r=$ & 0.90 & 0.93 & -0.72 & 0.24 \\
& $P=$ & 0.0001 & 0.0001 & 0.0003 & 0.3453 \\
\hline
\end{tabular}

a Test was conducted in 1994-95 using seed harvested in 1994.

${ }^{\mathrm{b}}$ FLS = flag leaf severity, which represents the percentage of flag leaf area with leaf streak symptoms.

${ }^{\mathrm{c}}$ Percentage of seeds from which $X$. translucens pv. translucens was recovered.

${ }^{d}$ Percentage of plants showing leaf streak symptoms from which $X$. translucens pv. translucens also was isolated (plants grown from contaminated seed). ered by a 14-m-long by 9-m-wide Quonset hut frame that was covered with polyethylene greenhouse film and open at both ends. This protected plants from rainfall and associated dispersal of bacteria. Soil was fertilized with $112.5 \mathrm{~kg}$ of 8-24-24 (N-P-K) per ha prior to planting and $45 \mathrm{~kg} \mathrm{~N} \mathrm{ha}^{-1}$ as ammonium nitrate on 5 February 1995 and 10 February 1996. Plants were watered carefully to minimize splashing between pots. Observations for characteristic BLS symptoms on plants in microplots were made until 15 weeks after planting. Disease incidence in plants grown from contaminated seeds was determined on 150 tillers randomly selected from each flag leaf disease class. Incidence on each tiller was expressed as the percentage of the flag leaf area showing BLS symptoms. Pathogen identity was confirmed by isolation on WBC and inoculation to Savannah wheat in a greenhouse as described previously.

Preliminary results from microplot tests showed an inverse relationship between seed germination and BLS severity on flag leaves of parent tillers. Therefore, we conducted additional tests to measure the effect of $X$. translucens pv. translucens on seed germination at various temperatures. Foundation grade cultivar Savannah and Florida 304 seeds free of $X$. translucens pv. translucens were used in seed germination test. These seeds were surface-sterilized for $2 \mathrm{~min}$ in $1 \% \mathrm{NaOCl}$ and rinsed in sterile distilled water. Surface-sterilized seeds were vacuum-infiltrated with a mixture of strains 90-1, 42, and 41 of $X$. translucens pv. translucens. Seeds were immersed in phosphate-buffered saline alone or containing $X$. translucens pv. translucens at $10^{8} \mathrm{CFU} \mathrm{ml}{ }^{-1}$, and vacuum $\left(2.70 \times 10^{5} \mathrm{~Pa}\right)$ was applied. After $5 \mathrm{~min}$, the vacuum was released, the bacterial suspension was poured off, and seeds were air-dried in a laminar flow hood and stored at $10^{\circ} \mathrm{C}$ for 30 days. Four 100-seed replicates for each treatment were placed on sterile moistened blotters in polycarbonate boxes with lids and kept in continuous darkness at 10, 15, 20 , and $25^{\circ} \mathrm{C}$. These represent the range of soil temperatures commonly encountered during late fall and early winter in Louisiana (11). Germination was measured after 7 days (1). Seeds with radicles $\geq 1 \mathrm{~cm}$ in length were considered germinated. This study was conducted twice.

Data from all experiments were analyzed using the CORR and GLM procedures of the Statistical Analysis System (SAS Institute, Cary, NC). When required, means were separated using least significant difference.

\section{RESULTS AND DISCUSSION}

Severity of BLS on flag leaves was much greater in 1994 than in 1995 (Tables 1 and 2). Rainfall in spring 1995 was less than average, which resulted in much lower BLS levels throughout the state. Consequently, there was a narrower range 
of BLS severity classes available for seed collection.

Parent tillers with more severe BLS on flag leaves had a greater percentage of seed infested by $X$. translucens pv. translucens as well as larger populations of $X$. translucens pv. translucens per seed (Tables 1 and 2). Positive correlation coefficients between flag leaf severity and both infested seed and bacterial populations in seed were significant for both cultivars in each year. These results imply a direct relationship between BLS severity on flag leaves and subsequent disease development on plants from seed produced on these parent tillers. These relatively high correlation coefficients in both years also suggest that, under conditions encountered in these experiments, dissemination of the pathogen within a given field was very limited, i.e., within a tiller or to others in close proximity. Under other circumstances, such as a rainstorm during seed development, bacteria might be splashed greater distances, thereby increasing the likelihood of spread to neighboring tillers.

Infested (contaminated) seed was detected only on parent tillers with flag leaf severity $\geq 15$ to $20 \%$ in $1994-95$ and $\geq 30$ to $35 \%$ in 1995-96 (Tables 1 and 2). These results suggest a threshold level for BLS severity on flag leaves that may be necessary for $X$. translucens pv. translucens to infect seed produced on that tiller. This could be an important concern during exchange of germ plasm or in efforts to restrict entry of the pathogen into new areas $(2,10,16)$.

Incidence of BLS symptoms on plants from seed produced on diseased plants was low $(\leq 3 \%)$ in our tests, which is similar to other reports for this bacterium $(10,20)$ and other seedborne bacterial plant pathogens (22). Both Hall et al. (10) and Sands et al. (20) reported transmission frequencies less than $2 \%$ even when individual seed infection levels were high. Under favorable conditions in growth chambers, Milus and Mirlohi (18) reported a 25\% frequency of transmission with this pathogen. It can be concluded from these studies, together with ours, that the level of transmission depends on the amount of seed infection, cultivar utilized, and environment in which the test is conducted. Despite low BLS incidence on plants from this seed, severity of BLS on tillers that produced the seed was high, i.e., up to $90 \%$ in 1994-95 and $40 \%$ in 1995-96. This suggests that neither high flag leaf severity nor high bacterial populations in seed alone necessarily result in severe disease. This may result from unfavorable environmental conditions, poor survival of epiphytic bacterial populations, or a combination of these as well as other factors that were not identified in these studies $(16,17)$.

It is possible that development of foliar symptoms on plants from this seed resulted from either epiphytic or systemic populations of the bacterium (27). Previous re- ports $(7,24)$, as well as our own observations, showed that winter wheat plants generally do not exhibit BLS symptoms until the onset of the reproductive stage. In Louisiana, this commonly represents about 4 months between planting and symptom onset. If contaminated seed is the sole source of primary inoculum, as suggested by several authors $(3,28)$, then $X$. translucens pv. translucens must persist as epiphytic or latent systemic populations for prolonged periods. The levels reached by these populations and the factors that induce them to become pathogenic have not been investigated. Tillman (24) suggested that BLS development may depend on favorable environmental conditions that coincide with susceptible plant growth stages. However, the specific roles for these host, environment, and pathogen factors have not been determined.
Parent tillers of Florida 304 with 20\% or more flag leaf severity produced seeds that demonstrated reduced germination in microplot tests (Tables 1 and 2). Analyses showed no significant test-by-treatment interactions for laboratory seed germination tests; therefore data from duplicate tests were combined for final analyses. Vacuum infiltration with $X$. translucens pv. translucens at a single concentration $\left(10^{8}\right.$ $\mathrm{CFU} \mathrm{ml} \mathrm{m}^{-1}$ ) reduced wheat seed germination in a manner that was both temperature and cultivar dependent (Table 3). The magnitude of this reduction was similar for both cultivars at $25^{\circ} \mathrm{C}$ but was much greater in Savannah at lower temperatures, i.e., 15 and $20^{\circ} \mathrm{C}$. Seed of both cultivars that were heat-treated to eliminate the pathogen germinated consistently well $(\geq 97 \%)$ across this temperature range. Germination was very low $(\leq 3 \%)$ at $10^{\circ} \mathrm{C}$ regardless of cul-

Table 2. Relationships between bacterial leaf streak severity on flag leaves, seed infested by Xanthomonas translucens pv. translucens, bacterial populations in seed, seedling emergence, and incidence of diseased plants in Baton Rouge, Louisiana ${ }^{\mathrm{a}}$

\begin{tabular}{lccccc}
\hline Cultivar & FLS $(\boldsymbol{\%})^{\mathbf{b}}$ & $\begin{array}{c}\text { Seed infested } \\
(\boldsymbol{\%})^{\mathbf{c}}\end{array}$ & $\begin{array}{c}\text { Bacterial population } \\
\text { (CFU/seed) }\end{array}$ & $\begin{array}{c}\text { Seedling } \\
\text { emergence }(\boldsymbol{\%})\end{array}$ & $\begin{array}{c}\text { Plants } \\
\text { diseased }(\boldsymbol{\%})^{\mathbf{d}}\end{array}$ \\
\hline Florida 304 & 0 & 0 & 0 & 100 & 0 \\
& 5 & 0 & 0 & 75 & 0 \\
& 10 & 0 & 0 & 75 & 0 \\
& 15 & 0 & 0 & 67 & 0 \\
& 20 & 0 & 0 & 58 & 0 \\
& 25 & 0 & 0 & 67 & 0 \\
& 30 & 1 & 448 & 58 & 1 \\
& 35 & 1 & 894 & 50 & 1 \\
& $r=$ & 0.66 & 0.67 & -0.76 & 0.39 \\
& $P a v a n n a h$ & 0.0001 & 0.0003 & 0.0001 & 0.0562 \\
& 0 & 0 & 0 & 100 & 0 \\
& 5 & 0 & 0 & 83 & 0 \\
& 10 & 0 & 0 & 75 & 0 \\
& 15 & 0 & 0 & 75 & 0 \\
& 20 & 0 & 0 & 75 & 0 \\
& 25 & 0 & 0 & 67 & 0 \\
& 30 & 0 & 0 & 75 & 0 \\
& 35 & 1 & 740 & 67 & 1 \\
& 40 & 4 & 1,286 & 58 & 2 \\
& $r=$ & 0.49 & 0.53 & -0.66 & 0.63 \\
& $P=$ & 0.0134 & 0.0042 & 0.0002 & 0.0016 \\
\hline
\end{tabular}

a Test was conducted in 1995-96 using seed harvested in 1995.

${ }^{\mathrm{b}}$ FLS = flag leaf severity, which represents the percentage of flag leaf area with leaf streak symptoms.

c Percentage of seeds from which $X$. translucens $\mathrm{pv}$. translucens was recovered.

${ }^{\mathrm{d}}$ Percentage of plants showing leaf streak symptoms from which $X$. translucens pv. translucens also was isolated (plants grown from contaminated seed).

Table 3. Germination of wheat seed following artificial infestation with Xanthomonas translucens pv. translucens

\begin{tabular}{llcccc}
\hline & & \multicolumn{4}{c}{ Seed germination (\%) } \\
\cline { 3 - 6 } Cultivar & Treatment $^{\mathbf{a}}$ & $\mathbf{1 0}^{\circ} \mathbf{C}$ & $\mathbf{1 5}^{\circ} \mathbf{C}$ & $\mathbf{2 0}^{\circ} \mathbf{C}$ & $\mathbf{2 5}^{\circ} \mathbf{C}$ \\
\hline Florida 304 & Control & $3^{\mathrm{b}}$ & $98^{* \mathrm{c}}$ & $97^{*}$ & $98^{*}$ \\
& Infested & 0 & 87 & 90 & 94 \\
Savannah & Control & 2 & $97^{*}$ & $98^{*}$ & $99^{*}$ \\
& Infested & 0 & 57 & 63 & 90 \\
\hline
\end{tabular}

a Seeds were surfaced-sterilized for $2 \mathrm{~min}$ in $1 \% \mathrm{NaOCl}$, rinsed in sterile distilled water, vacuuminfiltrated for $5 \mathrm{~min}$ with $X$. translucens pv. translucens in phosphate-buffered saline at $10^{8} \mathrm{CFU}$ $\mathrm{ml}^{-1}$, and germinated at $10,15,20$, or $25^{\circ} \mathrm{C}$. Control seeds were infiltrated with buffer alone. Seeds were stored at $10^{\circ} \mathrm{C}$ for 30 days.

${ }^{b}$ Values are means of four 100-seed replicates of each treatment.

${ }^{c}$ Within cultivars, asterisks indicate significant $(P \geq 0.05)$ difference between inoculated and control treatments for each temperature. Germination was measured after 8 days. 
tivar or treatment (Table 3). Previous studies showed that Savannah develops black chaff symptoms, whereas Florida 304 does not $(24,25)$. The fact that reduced seed germination was greater in Savannah may suggest that it is more closely related to black chaff reaction than to bacterial leaf streak reaction. Tests with a larger group of wheat genotypes will be needed to assess this possibility.

The mechanism by which $X$. translucens pv. translucens reduced seed germination was not clear. It may have resulted from direct action of the bacteria on the seed or from adverse effects on the flag leaf that indirectly affect seed germinability. However, the observation that seedling emergence was reduced in the absence of detectable bacteria (Tables 1 and 2) indicates that factors in addition to this pathogen may have functioned to reduce seedling emergence. Several explanations are possible. Heat treatment to eliminate the pathogen from wheat seed also may have eliminated other pathogens that can contribute to reduced germination but would not be detected in our studies. It is also possible that nondetectable populations of $X$. translucens pv. translucens were present in or on seed and that these were involved.

In a general discussion of seed vigor, Woodstock (29) reported that planting infected seed may have several deleterious effects, including reduced germination that results in thinner stands of weaker plants and provides initial inoculum for disease epidemics. These statements appear to be true for bacterial leaf streak on winter wheat in Louisiana. Our results indicate that $X$. translucens pv. translucens can be transmitted to developing seed, where it can reduce seed germination as well as influence BLS severity the following season. Use of wheat seed produced on infected plants may lower seed germination, reduce stands, and possibly establish disease foci that could initiate BLS epidemics.

\section{ACKNOWLEDGMENTS}

We thank O. M. Olanya and S. R. Stetina for reviewing this manuscript. This project was supported in part by the Louisiana Soybean and Small Grain Research and Promotion Board. Approved for publication by the Director of the Louisiana Agricultural Experiment Station as manuscript number 98-38-0190.

\section{LITERATURE CITED}

1. Association of Official Seed Analysts. 1988. Rules for testing seeds. J. Seed Technol. 2:1436.

2. Boosalis, M. G. 1952. Epidemiology of Xanthomonas translucens (J. J. and R.) Dowson on cereals and grasses. Phytopathology 42: 387-395.

3. Cunfer, B. M. 1987. Bacterial and fungal blights of foliage and heads of wheat. Pages 528-541 in: Wheat and Wheat Improvement. 2nd ed. E. G. Heynes, ed. ASA, Madison, WI.

4. Duveiller, E. 1990. Seed detection of Xanthomonas translucens pv. undulosa using a modification of Wilbrink's agar medium. Parasitica 40:3-17.

5. Duveiller, E. 1994. A pictorial series of disease assessment keys for bacterial leaf streak of cereals. Plant Dis. 78:137-141.

6. Duveiller, E., and Bragard, C. 1992. Comparison of immunofluorescence and two assays for detection of Xanthomonas translucens pv. undulosa in seeds of small grains. Plant Dis. 76:999-1003.

7. Duveiller, E., Bragard, C., and Maraite, H. 1991. Bacterial diseases in the warmer areasReality or myth? Pages 189-202 in: Proc. Wheat for Nontraditional Warm Areas. Int. Conf. Iguazu Falls. D. Sanders, ed. UNDP/ CIMMYT, Mexico City, Mexico.

8. Forster, R. L., and Schaad, N. W. 1988. Control of black chaff of wheat with seed treatment and a foundation seed health program. Plant Dis. 72:935-938.

9. Fourest, E., Rehms, L. D., Sands, D. C., Bjarko, M., and Lund, R. E. 1990. Eradication of Xanthomonas campestris pv. translucens from barley seed with dry heat treatments. Plant Dis. 74:816-818.

10. Hall, V. N., Kim, H. K., and Sands, D. C. 1981. Transmission and epidemiology of Xanthomonas translucens. (Abstr.) Phytopathology 71:878.

11. Harrison, S. A., Brown, L. P., Burns, D. R., Caylor, J., Collaku, A., Colyer, P. D., Habetz, R. J., Hallmark, W. B., Lanclos, D., Mascagni, H. J., Moore, R. H., Rabb, J., Reeder, M. E., Russin, J. S., Seale, C., Shadow, A., Slelton, W., Sistrunk, A., Tubajika, K. M., and Vermon, B. L. 1995. Performance of small grain varieties in Louisiana, 1995-1996. LAES Mimeo Series. No. 120.

12. James, W. C. 1971. An illustrated series of assessment keys for plant disease, their preparation and usage. Can. Plant Dis. Survey 51:39-65.

13. Jones, L. R., Johnson, A. G., and Reddy, C. S. 1916. Bacterial blight of barley and certain other cereals. Science 44:432-433.

14. Large, E. C. 1954. Growth stages in cereals Illustration of the Feekes Scale. Plant Pathol. 3:128-129.

15. Leben, C. 1981. How plant-pathogenic bacteria survive. Plant Dis. 65:633-637.

16. Mehta, Y. R. 1990. Management of Xanthomonas translucens pv. undulosa and horde through cereal seed testing. Seed Sci. Technol. 18:467-476.

17. Miller, T. D., and Schroth, M. N. 1972. Monitoring the epiphytic population of $\mathrm{Er}$ winia amylovora on pear with a selective medium. Phytopathology 62:1175-1182.

18. Milus, E. A., and Mirlohi, A. F. 1993. A test tube assay for estimating populations of Xanthomonas campestris pv. translucens on individual wheat leaves. Phytopathology 83:134-139.

19. Milus, E. A., and Mirlohi, A. F. 1995. Survival of Xanthomonas campestris pv. translucens between successive wheat crops in $\mathrm{Ar}-$ kansas. Plant Dis. 79:263-265.

20. Sands, D. C., Mizrak, G., Hall, V. N., Kim, H. K., Bockelman, H. E., and Gloden, M. J. 1986. Seed transmitted bacterial disease of cereals: Epidemiology and control. Arab J. Plant Prot. 4:127-125.

21. Schaad, N. W. 1988. Laboratory Guide for Identification of Plant Pathogenic Bacteria, 2nd ed. American Phytopathological Society, St. Paul, MN.

22. Schuster, M. L., and Coyne, D. P. 1974. Survival mechanisms of phytopathogenic bacteria. Annu. Rev. Phytopathol. 12:199-221.

23. Smith, E. F., Jones, L. R., and Reddy, C. S. 1919. The black chaff of wheat. Science 50:48.

24. Tillman, B. L. 1994. Breeding wheat for resistance to bacterial leaf streak caused by Xanthomonas translucens pv. translucens. Ph.D. diss. Louisiana State University, Baton Rouge.

25. Tillman, B. L., Harrison, S. A., Russin, J. S., and Clark, C. A. 1996. Relationship between bacterial streak and black chaff symptoms in winter wheat. Crop Sci. 36:74-78.

26. Tubajika, K. M., Tillman, B. L., Russin, J. S., Harrison, S. A., and Clark, C. A. 1996. Seed transmission and detection of Xanthomonas campestris pv. translucens in wheat. (Abstr.) Phytopathology 86:S80.

27. Wallin, J. R. 1946. Seed and seedling infection of barley, bromegrass, and wheat by Xanthomonas translucens var. cerealis. Phytopathology 36:446-457.

28. Wiese, M. V. 1987. Compendium of Wheat Diseases, 2nd ed. American Phytopathological Society, St. Paul, MN.

29. Woodstock, L. W. 1973. Physiological and biochemical tests for seed vigor. Seed Sci. Technol. 1:127-157. 